\author{
Anna Moskal * \\ ORCID: 0000-0001-9070-069X \\ Jagiellonian University
}

DOI: $10.19195 / 1733-5779.29 .3$

\title{
Mutual agreement procedure provided for in Directive $2017 / 1852$ as a remedy for the problem of double taxation in the European Union
}

\author{
JEL Classification: K3, K33
}

Keywords: double taxation, EU law, Directive 2017/1852

Słowa kluczowe: podwójne opodatkowanie, prawo UE, Dyrektywa 2017/1852

Abstract: In order to address the negative consequences of double taxation of the same income or capital belonging to a EU citizen, bi- and multilateral tax treaties have been concluded between the Member States. The EU legislator has enacted legislation introducing measures such as Directive 2003/49/EC, Directive 2011/96/EU and the EU Arbitration Convention to counteract the adverse effects of double taxation. Considering the imperfections in the previous procedures, the Council of the EU has issued Directive 2017/1852 on double taxation dispute resolution mechanisms in the EU, aiming to eliminate the existing shortcomings and to create a harmonized framework for dispute resolution. The aim of this article is to present the phenomenon of double taxation in the EU, to identify the shortcomings of the current mechanisms and to conduct a comprehensive analysis of the procedure provided for in Directive 2017/1852.

\section{Procedura wzajemnego porozumienia przewidziana w Dyrektywie 2017/1852 jako remedium na problem podwójnego opodatkowania w Unii Europejskiej}

Abstrakt: W praktyce obrotu gospodarczego UE niejednokrotnie dochodzi do podwójnego opodatkowania tego samego dochodu lub kapitału należącego do obywatela UE. W celu zniwelowania negatywnych konsekwencji podwójnego opodatkowania państwa członkowskie zawarły między sobą liczne bi- i multilateralne umowy podatkowe. Prawodawca uchwalił akty prawne wprowadzające środki przeciwdziałające niekorzystnym skutkom podwójnego opodatkowania, to jest Dyrektywę 2003/49/WE, Dyrektywę 2011/96/UE i tak zwaną unijną konwencję arbitrażową. Mając na uwa-

* Scientific Tutor (Opiekun naukowy) — prof. dr hab. Sławomir Dudzik 
dze niedoskonałości w dotychczasowych procedurach, Rada UE wydała Dyrektywę 2017/1852 w sprawie mechanizmów rozstrzygania sporów dotyczących podwójnego opodatkowania w UE, która dąży do wyeliminowania istniejących niedociągnięć oraz stworzenia sharmonizowanych ram rozstrzygania sporów. Celem artykułu jest przedstawienie zjawiska podwójnego opodatkowania w UE, wskazanie wad obecnie obowiązujących mechanizmów oraz dokonane analizy procedury przewidzianej w Dyrektywie 2017/1852.

\section{Introduction}

In recent decades, we have observed a dynamic development of economic trade between the Member States of the European Union. It is a natural consequence of the abolition of trade barriers in intra-Community trade, the introduction of a uniform customs tariff for external countries and the establishment of internal market freedoms. The single internal market not only forms the basis of the European Union ${ }^{1}$ but also contributes to the prosperity and growth in all Member States, to a significant extent. ${ }^{2}$ One of the key and immanent elements in the development of the Community market is the harmonization of the tax system at the EU level. It should be emphasized at the outset that in the current phase of creating an economic union, attempts are being made to coordinate the Member States' tax systems rather than to harmonize them fully and effectively. ${ }^{3}$ This is mainly due to the resistance of Member States to give up their competences in the fiscal area for the benefit of the Union. Tax systems are of considerable importance for the social and economic development of the Member States and guarantee their financial security. Moreover, they can be treated as tools of state authorities to stimulate entrepreneurship and innovation. ${ }^{4}$ Each country, acting within its own tax jurisdiction, has the possibility to determine its tax obligations independently and autonomously. As a result, different models of tax systems have been developed in different Member States.

${ }^{1}$ J. Barcz (ed.), Instytucje i prawo Unii Europejskiej. Podręcznik dla kierunków prawa, zarzadzania $i$ administracji, 4th ed., Warszawa 2015, p. 60.

${ }^{2}$ In the research conducted by the Parliament's Committee on Internal Market and Consumer Protection (IMCO) entitled "Contribution of the Internal Market and Consumer Protection to Growth" points to the significant potential of policies promoting free movement of goods, services, people and capital to boost the GDP (gross domestic product) of the EU-28, source: Study on Contribution of the Internal Market and Consumer Protection to Growth, study prepared for Parliament's Committee on the Internal Market and Consumer Protection, Policy Department A, 2014, http://www. europarl.europa.eu/RegData/etudes/STUD/2014/518762/IPOL_STU(2014)518762_EN.pdf (accessed: 1.09.2019).

${ }^{3}$ A. Kubicka, Systemy podatkowe w krajach Unii Europejskiej, Bielsko-Biała 2016, p. 16.

${ }^{4}$ European Commission, European Semester thematic factsheet taxation, 28.09.2017, p. 6, https:// ec.europa.eu/info/sites/info/files/file_import/european-semester_thematic-factsheet_taxation_en_1. pdf (accessed: 1.09.2019). 
The EU legislator regulated tax issues in Chapter 2 of Title VIII of Part III of the Treaty on the Functioning of the European Union (hereinafter: TFEU). This chapter, entitled "Tax provisions," prohibits tax discrimination and provides for the harmonization of national legislation on turnover taxes, excise duties and other indirect taxes (Article 113 TFEU). The fact that Treaty provisions refer only to indirect taxes may be a further reason for States' resistance to adopting EU directives harmonizing direct taxes. As a result, the regulation of personal income tax and corporate tax falls within the competence of individual Member States. It should be noted here that the EU citizens, taking advantage of the privileges resulting from the freedoms of the single internal market, may be subject to taxation in several countries. In such cases, undesirable situations may arise in which entities are subject to multiple tax burdens. The problem is particularly acute as there is no general prohibition of multiple or double taxation in public international law. 5

\section{The problem of double taxation in the European Union}

The term "double taxation" is defined and interpreted in various ways in the literature and jurisprudence. This discord results, inter alia, from the dual nature of the phenomenon, which can be analyzed both economically and legally. ${ }^{6}$ In economic terms, double taxation occurs when in a given financial year the same income or assets, but belonging to different economic entities, are taxed twice. ${ }^{7}$ In legal terms, however, the concept of double taxation must be understood to mean the levying of a tax on income or assets owned by the same entity by two independent authorities of different Member States which are independent of each other. ${ }^{8}$ In accordance with Article 2(1)(c) of Council Directive 2017/1852 of 10 October 2017 on double taxation dispute settlement mechanisms in the European Union" the term "double taxation" means the imposition by two or more Member States of taxes falling within the scope of the agreement or convention referred to in Article 1 in respect of the same income or taxable capital, if this leads to (i) additional tax expense, either (ii) an increase in tax liability or (iii) a write-off

${ }^{5}$ B. Kucia-Gościora, "Problematyka podwójnego opodatkowania w polskim prawie podatkowym," Rocznik Nauk Prawnych 10, 2000, no. 1, p. 196. Similarly: M. Bodych, "Zjawisko podwójnego opodatkowania i sposoby jego eliminacji," https://lexplay.pl/artykul/Prawo-Podatkowe/ Zjawisko-podwojnego-opodatkowania-i-sposoby-jego-eliminacji (accessed: 1.09.2019).

6 J. Głuchowski, Międzynarodowe prawo finansowe, Warszawa 1988, p. 70.

${ }^{7}$ N. Bărbuță-Mişu (ed.), The International Double Taxation - Causes and Avoidance, Florin 2009, pp. 150-151.

${ }^{8}$ Ibidem.

${ }^{9}$ Council Directive (EU) 2017/1852 of 10 October 2017 on tax dispute resolution mechanisms in the European Union, Official Journal of the European Union, L 265/1, https:/eur-lex.europa.eu/ legal-content/EN/TXT/HTML/?uri=CELEX:32017L1852\&from=EN (accessed: 1.09.2019). 
or reduction in losses against which taxable profits could be deducted. The EU legislator has therefore adopted a legal approach to double taxation. Double or multiple taxation is generally considered harmful because it creates serious fiscal obstacles for companies operating across borders and thus constitutes a restriction on the freedoms of the internal market. As rightly pointed out by the Council of the EU in the preamble to Directive 2017/1852, these obstacles "create an excessive tax burden for businesses and may cause economic distortions and efficiency losses and may also negatively affect cross-border investment and growth." 10 The European Commission has also rightly emphasized in its proposal for Directive $2017 / 1852,{ }^{11}$ that " double taxation' is one of the main problems currently faced by businesses operating across borders." 12 The Commission's position was supported in its opinion on Directive 2017/1852 ${ }^{13}$ European Economic and Social Committee. The validity of these theses is confirmed by statistical data showing that there are currently around 900 double taxation disputes in the European Union, around a substantial amount of EUR 10.5 billion. ${ }^{14}$

The European Union has been working for decades to build a stronger and more competitive market economy, creating jobs and further investment. ${ }^{15}$ In order to achieve these ambitious objectives, the Union aims to develop a fair and effective tax system. The European Commission has materially explained that "a fair system of taxation is not only about ensuring that profits are taxed where they are generated, but also about ensuring that profits are not subject to double taxation." 16 Although most European countries have concluded bi- and multilateral agreements to eliminate double taxation, they do not cover all taxes and all possible cross-border situations. With this in mind, over the last few years, the Union has adopted a number of instruments aimed at mitigating the adverse effects of double taxation. These include Council Directive 2003/49/EC on a common system of taxation applicable to interest and royalty payments made between

10 Preamble to the Council Directive 2017/1852, point 1.

${ }^{11}$ Proposal for a Council Directive on Double Taxation Dispute Resolution Mechanisms in the European Union COM/2016/0686 final - 2016/0338 (CNS) 2016/0338 (CNS), https://eur-lex.europa. eu/legal-content/EN/TXT/HTML/?uri=CELEX:52016PC0686\&from=EN (accessed: 1.09.2019).

12 Ibidem, p. 1.

13 Opinion of the European Economic and Social Committee on the proposal for a Council directive on double taxation dispute resolution mechanisms in the European Union (COM(2016) 686 final - 2016/0338 (CNS)), Official Journal of the European Union, C 173/29, point 1.2, https:// eur-lex.europa.eu/legal-content/EN/TXT/HTML/?uri=CELEX:52016AE6092\&from=EN (accessed: 1.09.2019).

${ }^{14}$ European Commission, Resolution of double taxation disputes in the European Union, https:// ec.europa.eu/taxation_customs/business/company-tax/resolution-double-taxation-disputes_en_ en\#heading_0 (accessed: 1.09.2019).

${ }^{15}$ European Union, Goals and values of the EU, https://europa.eu/european-union/about-eu/ eu-in-brief en (accessed: 1.09.2019).

16 Proposal for a Council Directive..., p. 2. 
associated companies of different Member States (hereinafter the IR Directive) ${ }^{17}$ and Council Directive 2011/96/EU on the common system of taxation applicable in the case of parent companies and subsidiaries of different Member States (hereinafter the PS Directive). ${ }^{18}$ Despite the acts undertaken, the Commission's annual analysis of double taxation cases showed that many cases could not be formally classified as a potential subject of the current dispute settlement mechanisms. ${ }^{19}$ Recognizing the problem identified on 25 October 2016 The Commission has made a proposal to propose a new Directive to complement and improve existing procedures and mechanisms. After a legislative process lasting almost 12 months on 10 October 2017, the Council of the EU issued Directive 2017/1852 on double taxation dispute resolution mechanisms in the European Union (hereinafter: Directive 2017/1852, the Directive). The Directive imposes on Member States the obligation to adopt provisions necessary to implement the Directive by 30 June 2019 and to immediately notify the Commission of their texts. ${ }^{20}$

\section{Directive $2017 / 1852$}

\subsection{Purpose and objectives}

In the preamble to the Directive, the Council of the EU indicated the ambitious goal of the act, which is to create a "more equitable tax environment" than the one currently functioning on the basis of tax agreements and conventions concluded between Member States, as well as provisions transposing directives and the EU Arbitration Convention. ${ }^{21}$ The most burning defects of the current rules, identified by the Council of the EU, ${ }^{22}$ were limited access to arbitration procedures, their length and the difficulties in concluding the case effectively. The solutions adopted are intended not only to eliminate the shortcomings identified, but to additionally create a harmonized and transparent framework for dispute resolution and

${ }^{17}$ Council Directive 2003/49/EC of 3 June 2003 on a common system of taxation applicable to interest and royalty payments made between associated companies of different Member States, Official Journal of the European Union, L 157/49, https://eur-lex.europa.eu/legal-content/EN/TXT/HTML/?uri=CELEX:32003L0049\&from=EN (accessed: 1.09.2019).

${ }^{18}$ Council Directive 2011/96/EU of 30 November 2011 on the common system of taxation applicable in the case of parent companies and subsidiaries of different Member States, Official Journal of the European Union, L 345/8, https://eur-lex.europa.eu/legal-content/EN/TXT/HTML/?uri=CELEX:32011L0096\&from=EN (accessed: 1.09.2019).

19 Therefore, they were not covered by the provisions transposing the EU directives, they did not fall under the cases settled under Convention 90/436/EEC on the elimination of double taxation in connection with the adjustment of profits of associated enterprises nor did they come within the scope of bilateral or multilateral tax agreements concluded by Member States.

${ }^{20}$ Art. 22 point 1 Council Directive 2017/1852.

${ }^{21}$ Point 4 with point 2 Preamble to the Council Directive 2017/1852.

22 Point 3 Preamble to the Council Directive 2017/1852. 
to ensure that taxpayers have a complete procedure to assert their rights. ${ }^{23}$ The EU legislator assumes that the regulations introduced in the Directive will lead to the creation of comprehensive, effective and sustainable mechanisms that will ensure legal certainty and an investment-friendly environment for companies. ${ }^{24}$ In order to achieve this objective, the mutual agreement procedures between the Member States concerned are to be improved by making them more flexible, shortening the duration and appeals against decisions taken in the course of proceedings.

\subsection{Subject matter and scope of application}

According to Article 1, the subject of the Directive are provisions establishing mechanisms for settling disputes between Member States arising in connection with the interpretation and application of currently binding bilateral agreements and conventions governing double taxation. In addition, the Directive regulates the rights and obligations of the persons concerned. It is important to note that the rules apply not only to legal persons but also to natural persons who are resident for tax purposes in the Member States and whose taxation is directly affected by the disputed issue. ${ }^{25}$ However, the EU legislator decided to differentiate certain procedures foreseen for different categories of addresses in order to reduce the administrative burden for individuals, micro, small and medium-sized enterprises. ${ }^{26}$

In comparison with previous legal acts regulating the settlement of double taxation disputes, the Directive has a very broad scope of application. Compared to the IR and PS Directives, the Directive does not limit its provisions only to certain categories of companies that meet certain shareholding requirements. Moreover, unlike Convention 90/436/EEC, which deals with double taxation only in the case of adjustment of profits of associated companies, Directive 2017/1852 aims to eliminate double taxation in all areas. It is also worth noting that, contrary to its name, the Directive will also apply to cases of multiple taxation, which may be deduced directly from the definition of "double taxation" introduced in the act, which, according to Article 2(1)(c), means the imposition of specified taxes "by two or more Member States."27

\subsection{Complaints procedure}

According to Article 3 of the Directive, any person in dispute has the possibility to submit a complaint against the double taxation imposed on him/her to the

23 Point 5 Preamble to the Council Directive 2017/1852.

${ }^{24}$ Points 4 and 5 Preamble to the Council Directive 2017/1852.

25 Art. 1 with Art. 2 point 1 let. d) Council Directive 2017/1852.

26 Point 7 Preamble to the Council Directive 2017/1852 and Art. 17 Council Directive 2017/1852.

${ }^{27}$ Art. 2 point 1 let. c) Council Directive 2017/1852. 
competent authorities of the Member States involved (hereafter also referred to as tax authorities) within 3 years of receiving the first notification of the double taxation measure. This power is available regardless of whether the taxpayer makes use of the legal remedies provided for in the national law of any of the Member States concerned. The recipients of the complaint confirm receipt of the letter within 2 months and inform the competent authorities of the other Member States involved. ${ }^{28}$ Subsequently, the tax authorities decide whether to accept or reject the complaint within 6 months. By introducing a six-month period for taking a decision, the Directive prevents this stage of the procedure from being protracted. This constitutes an improvement, in particular in relation to the double taxation dispute settlement mechanism provided for in Convention 90/436/EEC, which was strongly criticized precisely for not setting a maximum time limit for the authority to deal with the case before initiating the mutual agreement procedure. ${ }^{29}$ According to Directive 2017/1852 the authorities have the possibility to reject a complaint in three enumerated cases, which include: failure to provide the information required in the complaint, lack of double taxation and exceeding the three-year deadline for filing a complaint. ${ }^{30}$ The interested partieshave the right to appeal the decision to reject the complaint to all the organs of the national court. ${ }^{31}$ Authorities also have the possibility to decide on the resolution of a dispute unilaterally without the involvement of the authorities of another Member State. If all the authorities involved decide to accept the case, a mutual agreement procedure (MAP) is initiated, which is the heart of the whole mechanism.

\subsection{Mutual agreement procedure stage}

The mutual agreement procedure stage is regulated in Article 4 of the Directive. The MAP procedure generally takes up to two years from the last notification of a Member State's decision to accept a complaint. Exceptionally, this deadline may be extended by one year at the request of one of the following authorities. ${ }^{32}$ Under the Mutual Agreement Procedure, tax authorities are to determine how to resolve the issue of double taxation. If the authorities fail to reach a consensus, they will inform the complainant, who may then initiate an arbitration procedure. ${ }^{33}$ If, on the other hand, the authorities choose to settle the case, they will inform the complainant by means of a decision. Such a decision shall be binding

28 Interestingly, the European Commission proposed initially one month period.

${ }^{29}$ H.M. Pit, "Commission initiative to improve dispute settlement mechanisms within the European Union - The EU arbitration convention (90/436)," European Taxation 56, 2016, no. 11, p. 515.

${ }^{30}$ Art. 5 point 1 Council Directive 2017/1852.

31 Art. 5 point 3 Council Directive 2017/1852.

32 Art. 4 point 1 Council Directive 2017/1852.

${ }^{33}$ Art. 6 point 1 let. b) Council Directive 2017/1852. 
on the Authority provided that it is accepted by the applicant and that he waives any right to any other form of appeal. ${ }^{34}$ The decision adopted by the complainant is to be implemented immediately, without prejudice to any time limits laid down by national legislation.

\subsection{Procedure stage before the advisory commission}

Under Article 6 of the Directive, the complainant is entitled to request the establishment of an advisory commission in two cases - at the stage of the complaint procedure where the complaint is rejected by one or more but not all authorities and at the stage of the mutual agreement procedure where the authorities have not reached a consensus on how to resolve the matter ${ }^{35}$. In the first of these cases, the advisory commission shall decide whether to accept the complaint within six months of its establishment and shall notify the competent authorities within 30 days. Once it is decided by the advisory commission that a complaint is well-founded, the authorities have the possibility to apply for the MAP procedure. However, if none of the authorities decide to make such a request within 60 days of the date of notification of the decision, the advisory commission will itself impose a way of resolving the issue in its opinion. This opinion will be issued without following the procedure described above where a request for the establishment of a committee has been made at a stage of the mutual agreement procedure after the authorities have disagreed as to how the matter should be dealt with. ${ }^{36}$ The EU legislator also provides for a safeguard procedure in the event that no advisory commission is set up by the authorities within the legal deadline of 50 days. In such a case, the taxpayer concerned has the right to apply to the competent court or authority ${ }^{37}$ to establish a Consultative Commission. ${ }^{38}$

\subsection{Alternative to the proceedings before the advisory commission}

Although the above procedure is fully complete and guarantees the taxpayer a mechanism to decide how to resolve his case, the Directive also introduces an additional alternative procedure, the so-called "last chance arbitration" (also called "last resort arbitration"). ${ }^{39}$ This procedure involves issuing an opinion as to how the dispute should be resolved in any "soft" manner (which should include conciliation,

${ }^{34}$ Art. 4 point 6 Council Directive 2017/1852.

35 Art. 6 point 1 Council Directive 2017/1852.

${ }^{36}$ Art. 6 point 3 Council Directive 2017/1852.

37 The directive leaves up to the Member States a choose of the entity that will be responsible for setting up an advisory commission in case it is not set within the prescribed period.

${ }^{38}$ Art. 7 point 1 Council Directive 2017/1852.

39 Art. 10 point 1 Council Directive 2017/1852. 
mediation or any other alternative dispute resolution method) by an ad hoc or permanent out-of-court dispute resolution committee set up by the complaint handling bodies. ${ }^{40}$ The composition and form of such committees may be different from that of advisory committees, but the Directive strongly reserves for both types of committees the maintenance of the requirement of independence of members. ${ }^{41}$

\subsection{The resolution of disputes}

The Directive imposes an obligation on tax authorities to resolve the problem of double taxation within 6 months of receiving the opinion of an advisory or extrajudicial committee for dispute resolution. ${ }^{42}$ These opinions shall be binding on the authorities when they fail to reach a consensus on how to resolve the matter. If the authorities reach a common solution, they will be entitled to take a decision that departs from the opinion. ${ }^{43}$ The final decision is binding on all Member States and does not constitute a precedent for future cases. ${ }^{44}$ It is subject to enforcement within 60 days from the date of its notification to the taxpayer, which should take place immediately. If the decision is not enforced, the taxpayer may apply for enforcement to the courts of the Member State which has not complied with the decision. ${ }^{45}$

\section{Evaluation of the Directive}

In the opinion of the author of the article, contrary to the optimistic assumptions of the EU legislator, the examined Directive may not solve all the problems arising in this context, although the act undoubtedly improves the existing mechanisms for resolving double taxation disputes. The undeniable advantages of Directive 2017/1852 include a very broad scope of its application, the introduction of rigid and enforceable time frames and the provision of more effective procedural guarantees for taxpayers. In terms of these aspects, the Directive definitely stands out from the existing regulations and in fact improves the mechanisms for dispute resolution provided for by them.

In the opinion of the author of the article, the EU legislator did not manage to fully supervise the mechanisms that will be implemented by the Member States to implement the Directive. This act assumes that national courts will be responsible for monitoring progress in reaching a consensus on given issues and

\footnotetext{
40 Art. 10 point 2 Council Directive 2017/1852.

41 Ibidem.

42 Art. 15 point 1 Council Directive 2017/1852.

43 Art. 15 point 2 Council Directive 2017/1852.

${ }^{44}$ Art. 15 point 4 Council Directive 2017/1852.

45 Ibidem.
} 
for compliance with the deadlines set out in the Directive by advisory commissions. ${ }^{46}$ However, such a solution still does not guarantee that proceedings will be streamlined in terms of speeding up their duration where the authorities dealing with the case are delayed. It would be worth considering a de lege ferenda proposal to establish a permanent EU body, under the supervision of the European Commission, to assist advisory committees in the conduct of arbitration proceedings and to monitor compliance with the time limits set. ${ }^{47}$

The second disadvantage the author sees in the procedure provided for in the Directive is that the taxpayer's situation will be regularized in the first stage of the procedure when a complaint is rejected. Although the EU legislator has provided a very detailed "safeguard" procedure before an advisory commission when a taxpayer's complaint is rejected by one of the tax authorities involved, there is no similar solution if it is rejected by all tax authorities of the Member States involved. In such a situation, the complainant only has the option of having recourse to national remedies. It seems that such a regulation cannot be considered as a solution that would indeed fully meet the Directive's ambitious objective of creating a complete and unified procedure for resolving double taxation disputes, which would at the same time be effective in securing the taxpayer's position in the dispute and boosting his confidence in the tax system.

\section{Conclusions}

Summarizing these considerations, Directive 2017/1852 strongly favors the improvement of double taxation dispute resolution mechanisms. The EU legislator has successfully sought to correct deficiencies and shortcomings in the current regulations and has put in place well thought-out measures to counteract the negative effects of double taxation. However, Directive 2017/1852 is not without its drawbacks and further amendments are needed to achieve a fully effective and fair mechanism that genuinely ensures that taxpayers can effectively assert their rights. This is particularly important because unless Member States decide to fully harmonize their tax systems, double taxation will always be present in the EU internal market.

\section{References}

Bărbuţă-Mişu N. (ed.), The International Double Taxation - Causes and Avoidance, Florin 2009. Barcz J. (ed.), Instytucje i prawo Unii Europejskiej. Podręcznik dla kierunków prawa, zarządzania $i$ administracji, 4th ed., Warszawa 2015.

46 Art. 7 Council Directive 2017/1852.

47 That is what was proposed in relation to the analogous solution provided in Convention 90/436/EEC by H.M. Pit, op. cit., p. 515. 
Bodych M., "Zjawisko podwójnego opodatkowania i sposoby jego eliminacji," https://lexplay.pl/ artykul/Prawo-Podatkowe/Zjawisko-podwojnego-opodatkowania-i-sposoby-jego-eliminacji.

European Commission, European Semester thematic factsheet taxation, 28.09.2017, https://ec.europa.eu/info/sites/info/files/file_import/european-semester_thematic-factsheet_taxation_en_1. pdf.

European Commission, Resolution of double taxation disputes in the European Union, https://ec.europa.eu/taxation_customs/business/company-tax/resolution-double-taxation-disputes_en_en\#heading_0.

European Union, Goals and values of the EU, https://europa.eu/european-union/about-eu/eu-in-brief_ en.

Opinion of the European Economic and Social Committee on the proposal for a Council directive on double taxation dispute resolution mechanisms in the European Union (COM(2016) 686 final 2016/0338 (CNS)), Official Journal of the European Union, C 173/29, https://eur-lex.europa.eu/ legal-content/EN/TXT/HTML/?uri=CELEX:52016AE6092\&from=EN.

Głuchowski J., Międzynarodowe prawo finansowe, Warszawa 1988.

Głuchowski J., "Mullilalera le Abkommen der sozialistischer Lander über die Beseitigung der Doppelbesleuerung," Osteuropa Recht 32, 1986, no. 1.

Kubicka A., Systemy podatkowe w krajach Unii Europejskiej, Bielsko-Biała 2016.

Kucia-Gościora B., "Problematyka podwójnego opodatkowania w polskim prawie podatkowym," Rocznik Nauk Prawnych 10, 2000, no. 1.

Pit H.M., "Commission initiative to improve dispute settlement mechanisms within the European Union - The EU arbitration convention (90/436)," European Taxation 56, 2016, no. 11.

Study on Contribution of the Internal Market and Consumer Protection to Growth, study prepared for Parliament's Committee on the Internal Market and Consumer Protection, Policy Department A, 2014, http://www.europarl.europa.eu/RegData/etudes/STUD/2014/518762/IPOL_STU(2014)518762_ EN.pdf.

\section{Legal acts}

Council Directive 2003/49/EC of 3 June 2003 on a common system of taxation applicable to interest and royalty payments made between associated companies of different Member States, Official Journal of the European Union, L 157/49, https://eur-lex.europa.eu/legal-content/EN/TXT/HTML/?uri=CELEX:32003L0049\&from=EN.

Council Directive 2011/96/EU of 30 November 2011 on the common system of taxation applicable in the case of parent companies and subsidiaries of different Member States, Official Journal of the European Union, L 345/8, https://eur-lex.europa.eu/legal-content/EN/TXT/HTML/?uri=CE LEX:32011L0096\&from=EN.

Council Directive (EU) 2017/1852 of 10 October 2017 on tax dispute resolution mechanisms in the European Union, Official Journal of the European Union, L 265/1, https://eur-lex.europa.eu/ legal-content/EN/TXT/HTML/?uri=CELEX:32017L1852\&from=EN.

Proposal for a Council Directive on Double Taxation Dispute Resolution Mechanisms in the European Union COM/2016/0686 final - 2016/0338 (CNS) 2016/0338 (CNS), https://eur-lex.europa.eu/legal-content/EN/TXT/HTML/?uri=CELEX:52016PC0686\&from=EN. 